\title{
REDOX PROPERTIES OF RUTHENIUM COMPLEX WITH CATECHOL ARE INVOLVED IN TOXICITY TO GLIAL CELLS
}

\author{
WAGNER L. C. ALMEIDA ${ }^{1}$, DANIELA N. VITOR ${ }^{1}$, MARCO R. G. PEREIRA ${ }^{1}$, DENISE S. DE SÁ2 LISANDRO D. G. \\ ALVAREZ ${ }^{1}$, ALEXANDRE M. PINHEIRO ${ }^{1}$, SILVIA L. COSTA ${ }^{1}$, MARIA F. D. COSTA ${ }^{1}$, ZÊNIS N. DA ROCHA AND \\ RAMON S. EL-BACHÁ ${ }^{1, *}$
}

\author{
${ }^{1}$ Laboratório de Neuroquímica e Biologia Celular, Departamento de Biofunção, Instituto de Ciências da Saúde, Universidade Federal da Bahia, 40110-100, \\ Salvador, Bahia, Brasil, \\ ${ }^{2}$ Departamento de Química Geral e Inorgânica, Instituto de Química, Universidade Federal da Bahia, 41750-003, \\ Salvador, Bahia, Brasil \\ (Received 12 ${ }^{\text {th }}$ December 2007 - Accepted $1^{\text {st }}$ June 2007)
}

\begin{abstract}
Since the biological activity of $\left[\mathrm{Ru}^{\mathrm{III}}\left(\mathrm{NH}_{3}\right)_{4}(\text { catechol })\right]^{+}$has never been tested, its cytotoxicity to glial cells was assayed and correlated with its redox properties. Coordinated catechol oxidizes faster than catechol in the presence of oxygen, but controlled potential electrolysis showed that its oxidation involves only oneelectron. However, the oxidation of the free ligand by oxygen involves two electrons, which could generate more reactive oxygen species. Indeed, catechol was more cytotoxic than $\left[\mathrm{Ru}^{\mathrm{II}}\left(\mathrm{NH}_{3}\right)_{4}(\mathrm{catechol})\right]^{+}$complex to human glioblastoma GL-15 cells and also to rat astrocytes. $\left[\mathrm{Ru}^{\mathrm{III}}\left(\mathrm{NH}_{3}\right)_{4}(\mathrm{catechol})\right]^{+}$-induced cytotoxicity was related to the generation of reactive oxygen species and $\left[\mathrm{Ru}^{\mathrm{II}}\left(\mathrm{NH}_{3}\right)_{4} \text { (quinone) }\right]^{2+}$. However, other mechanisms should be involved since antioxidant enzymes and deferoxamine only partially protected GL-15 cells.
\end{abstract}

\section{INTRODUCTION}

Ruthenium is an element that has industrial, pharmaceutical and medical applications. Ruthenium can be used in the reduction of noxious oxides from industrial emissions ${ }^{1}$. Ruthenium dioxide and tetroxide are useful in oxidation reactions for the preparation of therapeutic compounds such as HIV protease inhibitors ${ }^{2},{ }^{3}$. Ruthenium can also be utilized to build medical devices, such as endoprostheses ${ }^{4}$. $\left[\mathrm{RuC}_{1}\left(\mathrm{NH}_{3}\right)_{5}\right]_{2}^{+}$has some interesting chemical and biological properties. $\left[\mathrm{RuC}_{1}\left(\mathrm{NH}_{3}\right)_{5}\right]_{2}{ }^{+}$can carry out electrocatalytic water oxidation ${ }^{5}$, it can bind to transferrin ${ }^{6}$, and has also been used in the preparation of ruthenium (II) complexes since chloride is rapidly displaced ${ }^{7,8}$.

Catechol is a compound that has also industrial and pharmaceutical applications. Catechol has been used as a protecting group in the synthesis of new drugs ${ }^{3}$, and it is also useful in synthetic chemistry because this compound has nucleophilic oxygen ${ }^{9}$. A number of novel estrane skeletons have been synthesized using catechol estrogens ${ }^{10}$. Catecholates are good siderophores, chelating various metals ${ }^{11}$.

In this article, $\left[\mathrm{RuCl}\left(\mathrm{NH}_{3}\right)_{5}\right] \mathrm{Cl}_{2}$ and catechol were used to synthesize $\left[\mathrm{Ru}^{\mathrm{III}}\left(\mathrm{NH}_{3}\right)_{4}(\text { catechol })\right]^{+12,13}$. As the biological activity of $\left[\mathrm{Ru}^{\mathrm{III}}\left(\mathrm{NH}_{3}\right)_{4}(\text { catechol })\right]^{+}$ complex was never tested, its cytotoxicity to glial cells was assayed. Glial cells were chosen because biomolecules bearing catechol groups are present in the central nervous system. Moreover, glial cells play important roles in physiological and pathological conditions such as neurodegenerative diseases, including Alzheimer's and Parkinson's diseases, and brain cancers like glioblastoma. The redox properties and the role of reactive oxygen species (ROS) in $\left[\mathrm{Ru}^{\mathrm{III}}\left(\mathrm{NH}_{3}\right)_{4}(\text { catechol) }]^{+}\right.$-induced cytotoxicity were also studied.

\section{EXPERIMENTAL}

\section{Chemistry}

In this study catechol was obtained from Riedel- de Haën (Buchs, Switzerland). $\left[\mathrm{Ru}^{\mathrm{III}}\left(\mathrm{NH}_{3}\right)_{4}(\mathrm{catechol})\right]$ was synthesized by dropping a solution containing $0.53 \mathrm{mmol}$ catechol in $7 \mathrm{M} \mathrm{NH}_{3}$ into a solution containing $0.34 \mathrm{mmol}\left[\mathrm{RuCl}\left(\mathrm{NH}_{3}\right)_{5}\right] \mathrm{Cl}_{2}$ in $7 \mathrm{M} \mathrm{NH}_{3}$ at $55^{\circ}{ }^{\circ} \mathrm{C}$ for 30 min under argon atmosphere. $\mathrm{NaBF}_{4}$ was added after $6 \mathrm{~h}$, and the mixture volume was reduced to dryness to give a blue solid crystal. The crude solid was washed with deaerated acetone/ethanol solution and excess ligand was removed. The product was purified under argon by a chromatographic technique. The complex was dissolved in a minimum water/ethanol $(1: 2)$ solution and placed on a column with dimensions of $10 \mathrm{~cm} \times 2 \mathrm{~cm}$ packed with neutral alumina. The complex was efficiently recovered by evaporation of the solvent under vacuum leading to the formation of a blue solid crystal, which was washed with deaerated ethanol (average yield: $62 \%$ ).

Analysis for $\mathrm{C}_{6} \mathrm{~N}_{4} \mathrm{H}_{2} \mathrm{O}_{2} \mathrm{RBF}_{4}$ (364.09), calculated C, 19.79; H, 4.43; N, 15.39; found C, $19.10 ; \mathrm{H}, 4.5 ; \mathrm{N}, 14.90$. Since elemental analysis of the compound was consistent with the formulation, conductometry measurements were not necessary. Complexes were also characterized by UV-visible and infrared spectra. Redox processes were studied using controlled potential electrolysis, cyclic voltammetry (CV) and differential pulse voltammetry (DPV). Electrochemical measurements were carried out in a PARC model 273 potentiostat - galvanostat, using a conventional three-electrode cell. Glassy carbon and platinum gauze were respectively used as working electrodes for voltammetry and coulometry, whereas $\mathrm{Ag} / \mathrm{AgCl}$ electrode was used as reference, and a platinum wire as auxiliary electrode. Spectroelectrochemical measurements were carried out using a gold mini-grid working electrode, $\mathrm{Ag} /$ $\mathrm{AgCl}$ as reference electrode and platinum wire as auxiliary electrode in a quartz cell with $0.3 \mathrm{~mm}$ optical path. Successive spectra were recorded during the redox process at $25^{\circ} \mathrm{C}$. $\left[\mathrm{Ru}^{\mathrm{II}}\left(\mathrm{NH}_{3}\right)_{4} \text { (quinone) }\right]^{2+}$ complex was synthesized from $\left[\mathrm{Ru}^{\mathrm{III}}\left(\mathrm{NH}_{3}\right)_{4}(\mathrm{catechol})\right]\left(\mathrm{BF}_{4}\right)$ in $1 \mathrm{M} \mathrm{HCl}$ by oxidation using controlled potential electrolysis at $+400 \mathrm{mV}$ versus $\mathrm{Ag} / \mathrm{AgCl}$ electrode, with a concomitant recording of sequential UV-Vis spectra. Following electrolysis, complex solution was evaporated to dryness leading to the formation of crystals. Methods used in this article verified the purity of the complexes and complemented the characterization by EPR and FT ${ }^{1} \mathrm{H}$ NMR published previously elsewhere ${ }^{12}$. This methodology is also in accordance to the characterization of analogous complexes ${ }^{13}$.

\section{Oxygen consumption}

Oxygen consumption rates during oxidation of 1 $\mathrm{mM}$ catechol $(\mathrm{n}=3)$ or $\left[\mathrm{Ru}^{\mathrm{III}}\left(\mathrm{NH}_{3}\right)_{4}(\text { catechol })\right]^{+} \quad(\mathrm{n}=5)$ in $50 \mathrm{mM}$ phosphate buffer (pH 7.4) at $37^{\circ} \mathrm{C}$ were measured using a Clark-type oxygen electrode connected to an oxygen monitoring system (YSY model 53 oxygen monitor, USA). Reaction rates were obtained from linear regression plots during the first 12 minutes. Results were compared using the Student's $t$-test. $\mathrm{P}<0.05$ was considered as a significant value.

\section{Glial cell cultures}

Isolated cortical astrocytes were prepared as described previously ${ }^{14}$. Briefly, astrocytes were prepared from the neocortex of 1-day-old Wistar rat brains, maintained in Dulbecco's modified Eagle's medium (DMEM, Cultilab, Campinas, Brazil) supplemented with $10 \%$ fetal calf serum (Cultilab), $2 \mathrm{mM}$ L-glutamine (Sigma, S. Paulo, Brazil), $100 \mathrm{IU} / \mathrm{mL}$ penicillin (Cultilab), and $100 \mu \mathrm{g} / \mathrm{mL}$ streptomycin (Cultilab). One-day-old Wistar rats were obtained from the Department of Physiology of the Health Sciences Institute, Federal University of Bahia (Salvador, BA, Brazil). Only four newborn rats were needed to obtain the necessary amount of cells to prepare primary astrocyte cultures. This minimum quantity of animals used in experimental protocols is according to the regulations established by the Ethical Committee for Animal Experimentation of the Federal University of Bahia. Further experiments were carried out using human glioblastoma GL-15 cell line of clonal origin, which has been previously established ${ }^{15}$. GL-15 cell cultures were prepared as described previously ${ }^{16}$. Cells were grown in a humidified $5 \% \mathrm{CO}_{2}$ and $95 \%$ air atmosphere at $37^{\circ} \mathrm{C}$, and the culture medium was replaced three times a week. At the time of the experiment, confluent cells were trypsinized and plated in 
a 96-well plate. Astrocytes were plated at a density of $7.8 \times 10^{4} \mathrm{cells} / \mathrm{cm}^{2}$ and GL-15 cells were plated at a final density of $3 \times 10^{4}$ cells $/ \mathrm{cm}^{2}$. Experiments were initiated 72 hours after plating.

\section{In vitro evaluation of cytotoxicity ${ }^{17}$}

Logarithmic dilutions in the range between $0.01 \mathrm{mM}$ and $6 \mathrm{mM}$ were used to examine catechol, $\left[\mathrm{Ru}^{\mathrm{III}}\left(\mathrm{NH}_{3}\right)_{4}(\text { catechol) }]^{+} \text {or }\left[\mathrm{Ru}^{\mathrm{II}}\left(\mathrm{NH}_{3}\right)_{4} \text { (quinone }\right)\right]^{2+}$ cytotoxic effects. Eight replicates were used for each dose per 96-well plate. Cells were exposed to catechol or complexes for 72 hours. Cell viability was assessed using the 3-(4,5-dimethylthiazol-2-yl)-2,5-diphenyltetrazolium bromide (MTT; Sigma) assay as described previously ${ }^{17}$. In brief, this colorimetric assay measures the MTT reduction by mitochondrial succinate dehydrogenase in intact cells. Because MTT reduction can only occur in metabolically active cells, the activity level has been used as a measure of cell viability. Cell viability was normalized to data measured under control conditions. Catechol and complex oxidation in the medium was monitored spectrophotometrically at $420 \mathrm{~nm}$, based on the formation of quinones ${ }^{18-21}$. Data were expressed as medians, $25 \%$, and $75 \%$ percentiles. A nonlinear regression was performed to fit concentration-response curves using GraphPad Prism Software (version 3.02, San Diego, USA). Data were analyzed using the Kruskal-Wallis nonparametric ANOVA method followed by the Student-Newman-Keuls post hoc test.

\section{Involvement of reactive oxygen species}

In order to study the involvement of ROS in the $\left[\mathrm{Ru}^{\text {III }}\left(\mathrm{NH}_{3}\right)_{4}(\text { catechol })\right]^{+}$ complex-induced GL-15 cell death, superoxide dismutase (SOD; $200 \mathrm{U}$; EC 1.15.1.1; Sigma; $\mathrm{n}=8$ ), catalase (CAT; 500 IU; EC 1.11.1.6; Sigma; $\mathrm{n}=8$ ), and the iron chelator deferoxamine (DFO; $0.6 \mathrm{mM}$; Sigma; $\mathrm{n}=7$ ) were incubated with $2.6 \mathrm{mM} \quad\left[\mathrm{Ru}^{\mathrm{III}}\left(\mathrm{NH}_{3}\right)_{4}(\mathrm{catechol})\right]^{+}$for $72 \mathrm{~h}$ at $37 \quad{ }^{\circ} \mathrm{C}$. Similarly, the effect of boiled inactivated catalase (iCAT; $n=5$ ) and SOD (iSOD, $n=4$ ) on complex-induced cell death was also studied. The protective effect of both SOD (200 U) and catalase (500 IU) was also investigated (Both; $\mathrm{n}=8$ ). Each group was compared to the control group or the group treated with the complex alone using the Student's $t$-test or the Mann-Whitney rank sum test depending on the normality test and the equal variance test.

\section{RESULTS AND DISCUSSION}

In neutral aqueous solution, catechol is unstable because it undergoes spontaneous oxidation constituted by a multi-step reaction process resulting in ROS, semiquinone and quinone formation. 1,2-Dioxolene ligands are redox-active molecules and their properties are modified when coordinated to transition metal ions. Since they are able to shuttle reversibly through the sequence quinone/semiquinone/catechol, their metal complexes can display both the ligand-centered and the metal-centered electron transfers, which in some cases can overlap or trigger internal charge reorganizations ${ }^{22}$. Hence, the redox properties of the complex were studied to better understand its biological effects.

The electrochemical behaviors of $\left[\mathrm{Ru}^{\mathrm{III}}\left(\mathrm{NH}_{3}\right)_{4}(\text { catechol })\right]^{+}$complex and catechol were examined. DPV of catechol showed a large anodic peak $\left(\mathrm{E}_{\mathrm{pa}}+525\right.$ $\mathrm{mV})$ associated with a cathodic peak $\left(\mathrm{E}_{\mathrm{pc}}+670\right)$. These peaks were attributed to the redox reaction catechol/semiquinone. Another observed cathodic peak $\left(\mathrm{E}_{\mathrm{pc}}-15 \mathrm{mV}\right)$ was attributed to the reduction of quinone to semiquinone. The formation of quinone is coupled to catechol/semiquinone electrode process. DPV and CV of ruthenium complex showed two pairs of peaks, one at a positive and another at a negative potential. The redox reaction catechol/semiquinone in the complex occurred at the positive potential $\left(\mathrm{E}_{\mathrm{pa}}+230 \mathrm{mV}, \mathrm{E}_{\mathrm{pc}}+190 \mathrm{mV}\right.$, $\left.\mathrm{E}_{\mathrm{f}}+210 \mathrm{mV}, i_{\mathrm{pc}} / i_{\mathrm{pa}} \cong 1\right)$. These data demonstrate that this electrode process is reversible and involves one electron. This monoelectronic process was further supported by controlled potential electrolysis, which showed a consumption of $1 \mathrm{~F} / \mathrm{mol}$. Peaks at more negative potentials $\left(\mathrm{E}_{\mathrm{pa}}-630 \mathrm{mV}, \mathrm{E}_{\mathrm{pc}}-720 \mathrm{mV}, \mathrm{E}_{\mathrm{f}}\right.$ $\left.-653 \mathrm{mV}, i_{\mathrm{pa}} / i_{\mathrm{pc}} \cong 0.8\right)$ occurred at the metal $\left(\mathrm{Ru}^{\mathrm{III}} / \mathrm{Ru}^{\mathrm{II}}\right)$ and this process also involves one-electron. However, $i / i$ ratio suggests a reversible process with a coupled reaction. According to data found for the free ligand and analogous $\left[\mathrm{Ru}^{\mathrm{III}}\left(\mathrm{NH}_{3}\right)_{4}(\text { catecholamine })\right]^{+}$complexes ${ }^{23,24}$, all these data, show that $\mathrm{Ru}^{\mathrm{III}}$ is coordinated to catecholate.

The spectrum of $\left[\mathrm{Ru}^{\mathrm{III}}\left(\mathrm{NH}_{3}\right)_{4}(\text { catechol })\right]^{+}$in phosphate buffer $(\mathrm{pH} 7.4)$ (Merck, Darmstadt, Germany) showed a band at $655 \mathrm{~nm}(\log \varepsilon$ 2.97), which was attributed to a ligand to metal charge transfer (LMCT) and another at $285 \mathrm{~nm}(\log \varepsilon$ 3.23) considered as internal ligand (IL). The electrochemical oxidation of $\left[\mathrm{Ru}^{\mathrm{III}}\left(\mathrm{NH}_{3}\right)_{4}(\text { catechol })\right]^{+}$complex at $400 \mathrm{mV}$ was monitored spectrophotometrically in the UV-Vis region. Spectra showed a progressive decrease of LMCT and IL bands, and the appearance of a new band of light absorption at $520 \mathrm{~nm}$ concomitant with ligand oxidation and a well-determined isosbestic point at $610 \mathrm{~nm}$ (Figure 1). These energy bands were also seen during $\left[\mathrm{Ru}^{\mathrm{III}}\left(\mathrm{NH}_{3}\right)_{4}(\text { catecholamine })\right]^{+}$complex oxidation ${ }^{23}$. The band at 520 $\mathrm{nm}$ was assigned to a metal to ligand charge transfer (MLCT), which probably arises from $\mathrm{d}_{\pi} \mathrm{Ru}^{\mathrm{II}} \rightarrow \pi^{*}$ (quinone) electronic transition during the oxidation of coordinated catechol to form $\left[\mathrm{Ru}^{\mathrm{II}}\left(\mathrm{NH}_{3}\right)_{4} \text { (quinone) }\right]^{2+}$.

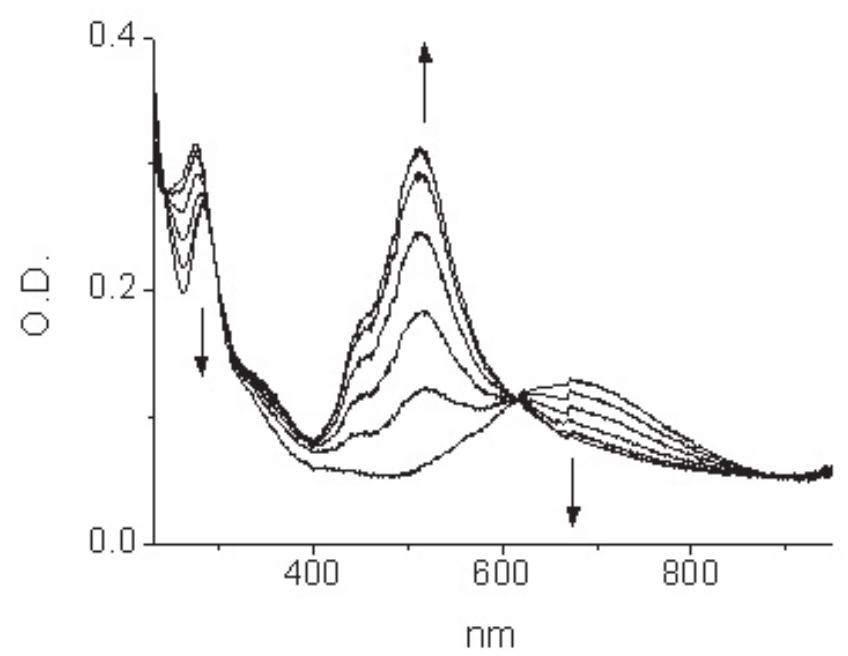

Figure 1: Absorption spectrum during the oxidation of $10^{-3} \mathrm{M}$ $\left[\mathrm{Ru}^{\mathrm{III}}\left(\mathrm{NH}_{3}\right)_{4}(\text { catechol })\right]^{+}$complex at $400 \mathrm{mV}$. Scans were repeated every three minutes.

Oxygen consumption rates during catechol and the complex oxidation were compared. Oxygen consumption increased approximately four times during 1 $\mathrm{mM}\left[\mathrm{Ru}^{\mathrm{III}}\left(\mathrm{NH}_{3}\right)_{4}(\text { catechol })\right]^{+}$oxidation $\left(2.47 \pm 0.18 \mu \mathrm{M} \cdot \mathrm{min}^{-1}\right)$ compared to the rate obtained for the free ligand under the same conditions $\left(0.58 \pm 0.01 \mu \mathrm{M} \cdot \mathrm{min}^{-1}\right.$; $\mathrm{P}<0.0001)$. These data agree with oxidation potentials measured by $\mathrm{CV}$ and DPV, which showed that the reaction of the complex with oxygen is more thermodynamically favored. However, the oxidation of catechol to quinone in the presence of oxygen involves two electrons meanwhile during the oxidation of the complex one electron reduces oxygen and the other is transferred to the metal.

Since the oxidation leads to the formation of ROS and reactive quinones, we investigated the cytotoxicity of catechol, $\left[\mathrm{Ru}^{\mathrm{III}}\left(\mathrm{NH}_{3}\right)_{4}(\text { catechol })\right]^{+}$, and $\left[\mathrm{Ru}^{\mathrm{II}}\left(\mathrm{NH}_{3}\right)_{4} \text { (quinone) }\right]^{2+}$ to glial cells.

Catechol- and $\left[\mathrm{Ru}^{\mathrm{III}}\left(\mathrm{NH}_{3}\right)_{4}(\text { catechol })\right]^{+}$-induced cytotoxicity to rat astrocytes was studied to determine the concentration that kills effectively $50 \%$ of cells $\left(\mathrm{EC}_{50}\right)$. Catechol- and also complex-induced cytotoxicity depended on the concentration of these compounds (Figure 2).

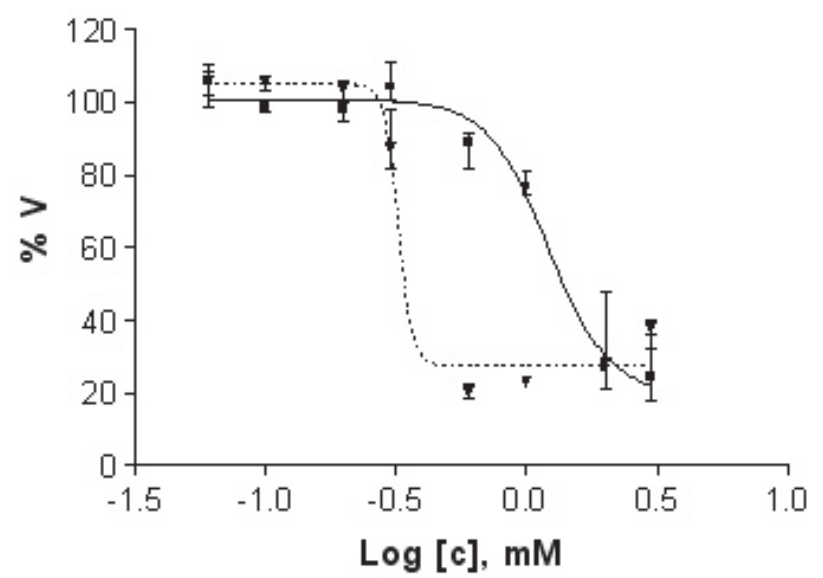

Figure 2: Dependence of the astrocyte viability $(\% \mathrm{~V})$ on the logarithmic concentration $(\log [\mathrm{c}], \mathrm{mM})$ of catechol $(\nabla---\nabla)$ or $\left[\mathrm{Ru}^{\mathrm{III}}\left(\mathrm{NH}_{3}\right)_{4}(\text { catechol })\right]^{+}$ 
Catechol-induced cytotoxicity was fitted to equation [1]:

$\mathrm{V}=27.45+\left\{77.35 /\left[1+10^{(7.99+16.30 \log [\mathrm{c}]}\right]\right\} ;\left(\mathrm{R}^{2}=0.9838\right)$

in which $\mathrm{V}$ corresponds to cell viability normalized to data measured under control conditions, and [c] is the catechol concentration. The calculated $\mathrm{EC}_{50}$ for catechol on astrocytes after 72 hours was $0.342 \mathrm{mM}$. Complex-induced cytotoxicity was fitted to equation [2]:

$$
\mathrm{V}=19.57+\left\{81.03 /\left[1+10^{(-0.31+3.75 \log [c])}\right]\right\} ;\left(\mathrm{R}^{2}=0.9862\right)
$$

The calculated $\mathrm{EC}_{50}$ for the complex was $1.380 \mathrm{mM}$. It means that the complex was 4-fold less toxic than catechol to rat astrocytes, probably because less ROS is formed during its oxidation.

Catechol-induced cytotoxicity to human GL-15 glioblastoma cells was also studied (Figure 3). Catechol-induced cytotoxicity depended on its concentration and was fitted to equation [3]:

$$
\mathrm{V}=30.75+\left\{70.25 /\left[1+10^{(1.27-3.45 \log [\mathrm{c}]}\right]\right\} ;\left(\mathrm{R}^{2}=0.9945\right)
$$

The $\mathrm{EC}_{50}$ for catechol on GL-15 cells, after 72 hours, was $0.568 \mathrm{mM}$. This means that catechol is 1.7 -fold less toxic to human GL-15 cells than to rat astrocytes. Furthermore, the formation of quinone increased with catechol concentration and was fitted to equation [4]:

$$
\text { O.D. }{ }_{420 \mathrm{~nm}}=-0.01+\left\{0.63 /\left[1+10^{(-0.84-1.59 \log [\mathrm{c}]}\right]\right\} ;\left(\mathrm{R}^{2}=0.9987\right)
$$

in which O.D. ${ }_{420 \mathrm{~mm}}$ corresponds to optical densities measured at $420 \mathrm{~nm}$ that correlates to the formation of quinone in the medium, and [c] is the catechol concentration. In this study it was found that there is a trend in cell viability to decrease depending on the formation of quinone according to equation [5]:

$$
\mathrm{V}=-154.6 \text { O.D }_{420 \mathrm{~nm}}+123.1 ;\left(\mathrm{R}^{2}=0.9353 ; \mathrm{P}<0.002\right)
$$

Another study also showed that catechol-induced cytotoxicity to GL-15 cells is associated with the formation of quinones ${ }^{25}$.

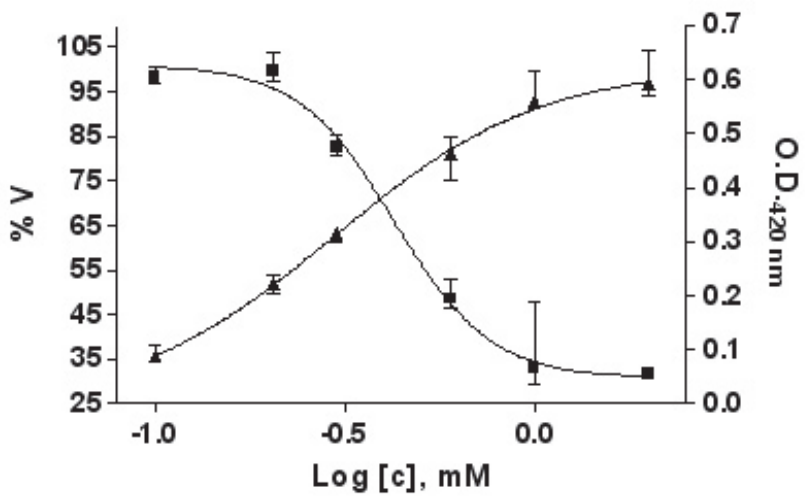

Figure 3: Dependence of GL-15 cell viability (\% V; - a ) and the formation of quinone (O.D. ${ }_{420 \mathrm{~mm}} ; \boldsymbol{-}$ - $)$ ) on logarithmic concentration (log [c], mM) of catechol.

$\left[\mathrm{Ru}^{\mathrm{III}}\left(\mathrm{NH}_{3}\right)_{4}(\text { catechol })\right]^{+}$-induced cytotoxicity to human GL-15 glioblastoma cells also depended on its concentration (Figure 4) and was fitted to equation [6]:

$$
\mathrm{V}=13.08+\left\{84.95 /\left[1+10^{(-1.27+3.36 \log [\mathrm{cc})}\right]\right\} ;\left(\mathrm{R}^{2}=0.9889\right)
$$

The $\mathrm{EC}_{50}$ for the complex on GL-15 cells, after 72 hours, was $2.600 \mathrm{mM}$. It means that human glioblastoma cells were 1.9-fold more resistant to the complex than rat astrocytes, and that the complex was 4.6-fold less toxic than catechol to GL-15 cells. Once again, the formation of quinone increased with the concentration of the complex and was fitted to equation [7]:

$$
\text { O.D }_{420 \mathrm{~nm}}=41 /\left[1+10^{(2.33-0.83 \log [\mathrm{cc})}\right] ;\left(\mathrm{R}^{2}=0.9939\right)
$$

There was also a trend in cell viability to decrease depending on the formation of quinone according to equation [8]:

$$
\mathrm{V}=-110.6 \text { O.D. } \cdot_{420 \mathrm{~nm}}+105.7 ;\left(\mathrm{R}^{2}=0.9620 ; \mathrm{P}<0.0001\right)
$$

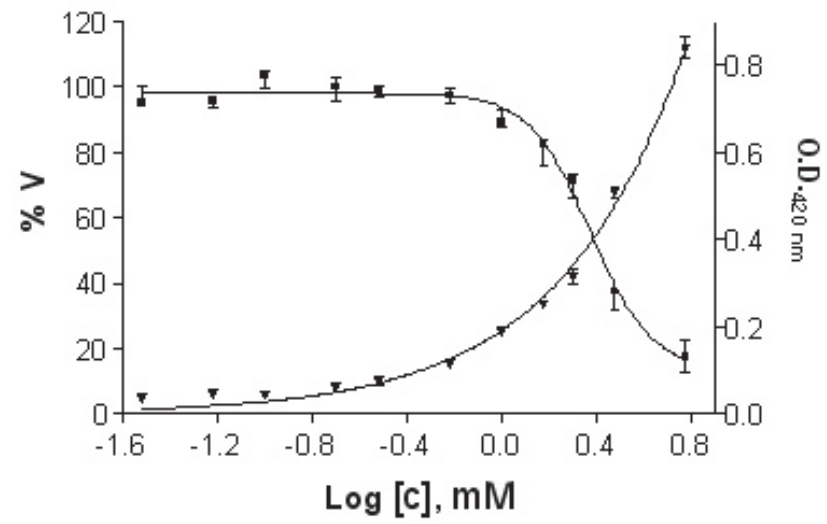

Figure 4: Dependence of GL-15 cell viability (\% V; _ _ _ and the formation of quinone (O.D. . $_{420 \mathrm{~mm}} ; \boldsymbol{-}$ ) on logarithmic concentration (log $[\mathrm{c}], \mathrm{mM})$ of $\left[\mathrm{Ru}^{\mathrm{III}}\left(\mathrm{NH}_{3}\right)_{4} \text { (catechol) }\right]^{+}$.

Sincetherewasaninverselinearcorrelationbetween $\left[\mathrm{Ru}^{\mathrm{III}}\left(\mathrm{NH}_{3}\right)_{4}(\text { catechol })\right]^{+}$induced cytotoxicity and the formation of quinone, $\left[\mathrm{Ru}^{\mathrm{II}}\left(\mathrm{NH}_{3}\right)_{4} \text { (quinone) }\right]^{2+}$ induced toxicity to GL-15 cells was tested (Figure 5). Quinone-induced cytotoxicity also depended on its concentration and was fitted to equation [9]:

$$
\mathrm{V}=8.28+\left\{90.44 /\left[1+10^{(-0.04+3.59 \log [\mathrm{cc})}\right]\right\}\left(\mathrm{R}^{2}=1.00\right)
$$

The $\mathrm{EC}_{50}$ for $\left[\mathrm{Ru}^{\mathrm{II}}\left(\mathrm{NH}_{3}\right)_{4}(\text { quinone })\right]^{2+}$ on GL-15 cells, after 72 hours, was $1.073 \mathrm{mM}$. This means that the oxidized complex was 2.4 -fold more toxic than $\left[\mathrm{Ru}^{\mathrm{III}}\left(\mathrm{NH}_{3}\right)_{4} \text { (catechol) }\right]^{+}$.

To examine the role of ROS on $\left[\mathrm{Ru}^{\mathrm{III}}\left(\mathrm{NH}_{3}\right)_{4}(\mathrm{catechol})\right]^{+}$complex-induced cytotoxicity, we evaluated the effects of antioxidant enzymes, such as SOD and catalase, and also the iron chelator DFO. A complete protection was not achieved by any treatment. However, SOD and catalase, alone or associated, and also DFO protected cells partially but significantly against complex-induced cytotoxicity (Figure 6). These results showed that complex cytotoxicity is at least in part mediated by ROS and iron. We showed previously that catecholinduced toxicity to GL-15 cells is also due to the formation of superoxide and reactive quinones ${ }^{25}$.

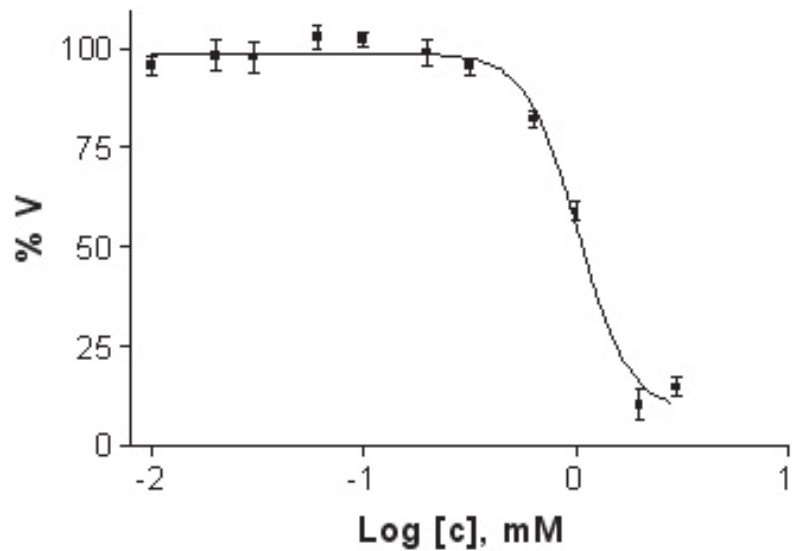

Figure 5: Dependence of GL-15 cell viability (\% V) on logarithmic concentration $(\log [\mathrm{c}], \mathrm{mM})$ of $\left[\mathrm{Ru}^{\mathrm{II}}\left(\mathrm{NH}_{3}\right)_{4} \text { (quinone) }\right]^{+}$. 


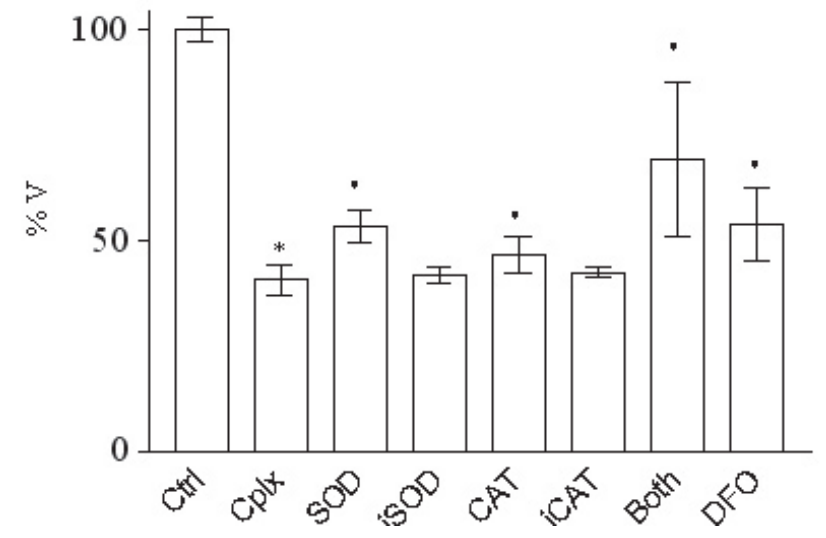

Figure 6: Dependence of $\left[\mathrm{Ru}^{\text {III }}\left(\mathrm{NH}_{3}\right)_{4}(\text { catechol })\right]^{+}$complex-induced cytotoxicity to GL-15 cells on ROS generation. *, P $<0.0005$ vs. control group (Ctrl). $\bullet, \mathrm{P}<0.01$ vs. cells treated with the complex alone (Cplx).

\section{CONCLUSIONS}

This study investigated for the first time $\left[\mathrm{Ru}^{\mathrm{III}}\left(\mathrm{NH}_{3}\right)_{4}(\text { catechol })\right]^{+}$-induced cytotoxicity. Catechol was more cytotoxic than $\left[\mathrm{Ru}^{\mathrm{II}}\left(\mathrm{NH}_{3}\right)_{4}(\text { catechol })\right]^{+}-$ complex to human glioblastoma GL-15 cells and also rat astrocytes. Although the coordinated catechol oxidizes faster than catechol in the presence of oxygen, controlled potential electrolysis showed that oxidation to quinone involves only one-electron. However, the oxidation of the free ligand to quinone by oxygen involves two electrons, which could lead to more ROS generation. Experiments involving SOD, catalase and deferoxamine showed that oxidative stress is an important, but not unique, cytotoxic pathway. The formation of $\left[\mathrm{Ru}^{\mathrm{II}}\left(\mathrm{NH}_{3}\right)_{4} \text { (quinone) }\right]^{2+}$ is also responsible for the complexinduced cytotoxicity. To better understand the cytotoxicity of the complex, other mechanisms of cell death must be studied.

\section{ACKNOWLEDGEMENTS}

We are grateful to FAPESB, CNPq, CAPES and BNB.

\section{REFERENCES}

1. G. Yaluris, J. A. Rudesill, US Patent 7030055, 2006.

2. M. N. Arimilli, M. M. Becker, C. Bryant, J. M. Chen, X. Chen, A. Dastgah, M. Fardis, G.-X. He, H. Jin, C. U. Kim, W. A. Lee, C. P. Lee, K.-Y. Lin, H. Liu, R. L. MacKman, M. L. Mitchell, P. H. Nelson, H.-J Pyun, T. D. Rowe, M. Sparacino, S. Swaminathan, J. D. Tario, J. Wang, M. A. Williams, L. Xu, Z.-Y Yang, R. H. Yu, J. Zhang, L. Zhang, US Patent Appl. 20050209197, 2005.

3. M. N. Arimilli, M. M. Becker, G. Birkus, C. Bryant, J. M. Chen, X. Chen,
T. Cihlar, A. Dastgah, E. J. Eisenberg, M. Fardis, M. Hatada, G.-X. He, H. Jin, C. U. Kim, W. A. Lee, C. P. Lee, K.-Y. Lin, H. Liu, R. L. MacKman, M. J. McDermott, M. L. Mitchell, P. H. Nelson, H.-J. Pyun, T. D. Rowe, M. Sparacino, S. Swaminathan, J. D. Tario, J. Wang, M. A. Williams, L. Xu, Z.-Y. Yang, R. H. Yu, J. Zhang, L. Zhang, US Patent Appl. 20050239054 , 2005.

4. L. L. Atanasoska, J. Weber, M. J. Miller, US Patent Appl. 20060100696 , 2006.

5. M. Yagi, T. Yamaguchi, M. Kaneko, J. Mol. Cat. A, 149, 289 (1999).

6. D. R. Frasca, L. E. Gehrig, M. J. Clarke, J. J. Inorg. Biochem. 83, 139 (2001).

7. H. C. Bajaj, P. A. Tregloan, R. van Eldik, R. Inorg. Chem. 43, 1429(2004)

8. E. Tfouni, K. Q. Ferreira, F. G. Doro, R. S. da Silva, Z. N. da Rocha, Coord. Chem. Rev. 249, 405 (2005).

9. T. Takai, Y. Tanaka, Y. US Patent Appl. 20060106181, 2006.

10. J. R. Hanson, Nat. Prod. Rep. 23, 100 (2006).

11. J. A. Tuszynski, K. Goss, H. J. Greenwald, G. F. Fritz, US Patent Appl. 20050249667, 2005.

12. S. D. Pell, R. B. Salmonsen, A. Abelleira, M. Clarke, J. Inorg. Chem. 23, 385 (1984).

13. R. S. da Silva, S. I. Gorelsky, E. S. Dodsworth, E. Tfouni, A. B. P. Lever, J. Chem. Soc. Dalton Trans. 4078 (2000).

14. J. Booher, M. Sensenbrenner, Neurobiology, 2, 97 (1972).

15. V. Bocchini, R. Casalone, P. Collini, G. Rebel, F. Lo Curto, F. Cell Tissue Res. 265, 73 (1991).

16. T: Planchenault, S. L. Costa, C. Fages, D. Riche, C. Charrière-Bertrand, A. Perzelova, G. Barlovatz-Meimon, M. Tardy, Neurosci. Let. 299, 140 (2001).

17. M. B: Hansen, S. E. Nielsen, K. Berg, K. J. Immunol. Methods, 119, 203 (1989).

18. C. T. Lai, P. H. Yu, Biochem. Pharmacol. 53, 363 (1997).

19. L. A. Burzio, J. H. Waite, J. H. Biochem. 39, 11147 (2000).

20. A. W. Boots, G. R. M. M. Haenen, G. J. M.; den Hartog, Bast, A. Biochim. Biophys. Acta, 1583, 279 (2002).

21. G. Toscano, M. L. Colarieti, G. Greco Jr., Enz. Microb. Technol. 33, 47 (2003).

22. P. Zanello, M. Corsini, M. Coord. Chem. Rev. 250, 2000 (2006).

23. R. G. de Lima, M. S. P. Marchesi, M. A. F. de Godoy, A. O. Cassano, A. M. de Oliveira, R. S. da Silva, R. S. Int. J. Pharm. 271, 21 (2004).

24. R. G. de Lima, A. B. P. Lever, I. Y. Ito, R. da Silva, Transition Met. Chem. 28, 272 (2003).

25. M. R. G. Pereira, E. S. de Oliveira, F. A. G. A. de Villar, M. S. Grangeiro, J. Fonseca, A. R. Silva, M. F. D. Costa, S. L. Costa, R. S. El-Bachá, J. Bras. Patol. Med. Lab. 40, 281 (2004). 